\title{
Aerosolized bovine lactoferrin reduces neutrophils and pro- inflammatory cytokines in mouse models of Pseudomonas aeruginosa lung infections
}

\begin{tabular}{|r|l|}
\hline Journal: & Biochemistry and Cell Biology \\
\hline Manuscript ID & bcb-2016-0050.R1 \\
\hline Manuscript Type: & Article \\
\hline Date Submitted by the Author: & 09-Jun-2016 \\
\hline Complete List of Authors: & $\begin{array}{l}\text { Valenti, Piera; Sapienza University of Rome, Public Health and Infectious } \\
\text { Diseases } \\
\text { Frioni, Alessandra; SAPIENZA UNIVERSITY OF ROME } \\
\text { Rossi, Alice; IRCCS - San Raffaele Scientific Institute, Milan, Italy, Infection } \\
\text { and Cystic Fibrosis Unit, Division of Immunology, Transplantation and } \\
\text { Infectious Diseases } \\
\text { Ranucci, Serena; IRCCS - San Raffaele Scientific Institute, Milan, Italy, } \\
\text { Infection and Cystic Fibrosis Unit, Division of Immunology, Transplantation } \\
\text { and Infectious Diseases } \\
\text { De Fino, Ida; IRCCS - San Raffaele Scientific Institute, Milan, Italy } \\
\text { Cutone, Antimo; University of Rome, La Sapienza } \\
\text { rosa, luigi; University of Rome, La Sapienza } \\
\text { Bragonzi, Alessandra; IRCCS - San Raffaele Scientific Institute, Milan, } \\
\text { Italy, Infection and Cystic Fibrosis Unit, Division of Immunology, } \\
\text { Transplantation and Infectious Diseases } \\
\text { Berlutti, Francesca; SAPIENZA UNIVERSITY, PUBLIC HEALTH AND } \\
\text { INFECTIOUS DISEASES }\end{array}$ \\
\hline Keyword: & $\begin{array}{l}\text { Bovine lactoferrin, Lung infection, Inflammation, Pseudomonas aeruginosa, } \\
\text { Cystic fibrosis }\end{array}$ \\
\hline \hline
\end{tabular}

\section{SCHOLARONE \\ Manuscripts}


Aerosolized bovine lactoferrin reduces neutrophils and pro-inflammatory cytokines in mouse models of Pseudomonas aeruginosa lung infections

Valenti Piera ${ }^{1}$, Frioni Alessandra ${ }^{1}$, Rossi Alice ${ }^{2}$, Ranucci Serena ${ }^{2}$, De Fino Ida ${ }^{2}$, Cutone Antimo ${ }^{1}$, Rosa Luigi ${ }^{1}$, Bragonzi Alessandra ${ }^{2}$, and Berlutti Francesca ${ }^{1^{*}}$

${ }^{1}$ Department of Public Health and Infectious Diseases, Sapienza University, Rome, Italy;

${ }^{2}$ Infection and Cystic Fibrosis Unit, Division of Immunology, Transplantation and Infectious Diseases, IRCCS - San Raffaele Scientific Institute, Milan, Italy

*Corresponding Author

Francesca Berlutti

Department of Public Health and Infectious Diseases

Sapienza University of Rome

P.zzale A. Moro,5

00185 Rome, Italy

e-mail: francesca.berlutti@uniroma1.it 


\section{Abstract}

Lactoferrin (Lf), an iron-chelating glycoprotein of the innate immunity, produced by exocrine glands and neutrophils in infection/inflammation sites, is one of the most abundant defence molecules in airway secretions. Lf, a pleiotropic molecule, exerts antibacterial and antiinflammatory functions. These properties may play a relevant role in airway infections characterized by exaggerate inflammatory response as in Pseudomonas aeruginosa lung infection in cystic fibrosis (CF) subjects.

To verify the Lf role in Pseudomonas aeruginosa lung infection, here we evaluated the efficacy of aerosolized bovine Lf (bLf) in mouse models of $P$. aeruginosa acute and chronic lung infections. C57BL/6NCrl mice were challenged with $10^{6} \mathrm{CFUs}$ of $P$. aeruginosa PAO1 (acute infection) or MDRRP73 strain (chronic infection) by intra-tracheal administration. In both acute and chronic infections, aerosolized bLf determined not-significant reduction of bacterial load but significant decrease of the neutrophil recruitment and pro-inflammatory cytokine levels. Moreover, in chronic infection the bLf-treated mice recovered the body weight faster and at higher extent than the control mice.

These findings add new insights into the benefits of bLf as a mediator of general health and its potential therapeutic applications.

\section{Key words}

Bovine lactoferrin; Lung infection; Inflammation; Pseudomonas aeruginosa; Cystic fibrosis 
Introduction

Lactoferrin (Lf), a multifunctional glycoprotein able to chelate two $\mathrm{Fe}^{3+}$ ions per molecule with high affinity, is found in mucosal secretions and secreted by neutrophils in infection/inflammation sites. it exerts the bacteriostatic activity related to its ability in sequestering iron required for microbial survival and growth, and, the bactericidal, anti-adhesive and anti-invasive activities related to its binding to bacterial or host cell surface components, independently from its iron-binding function (Valenti et al. 2004; Valenti and Antonini 2005). Noteworthy, Lf exerts anti-inflammatory activity, contributing to mucosal protection from inflammation-related damage (Berlutti et al. 2006; Valenti et al. 2011; Legrand 2012; Latorre et al. 2012). This property may be relevant in inflammatory diseases as cystic fibrosis (CF) airways infections in which the exaggerate inflammation that can precede the bacterial infection (Dakin et al. 2002; Verhaeghe et al. 2007) negatively correlates with lung functionality, cell damage, and disease severity sustained by Pseudomonas aeruginosa (Reid et al. 2007; O'Sullivan and Flume 2009; Cohen and Prince 2012; Smith et al. 2014). Despite to the improvement of infection therapy based on aerosolized antibiotics (Waters and Smyth 2015), chronic Pseudomonas aeruginosa infections remain very difficult to treat (Gibson et al. 2003; Vidya et al. 2015). Therefore, there is the need to develop new therapeutic strategies not based on the use of antibiotics but with pleiotropic agents to treat $P$. aeruginosa lung infection.

Lf that is one of the most abundant factors of natural immunity in airway secretions (Travis et al. 1999), could represent a good candidate for its antibacterial and anti-inflammatory properties. Interestingly, bovine milk derivative-Lf (bLf) induced a dramatic decrease of pro-inflammatory cytokines in in vitro CF human airway epithelium infected with P. aeruginosa (Frioni et al. 2014).

To confirm the potential beneficial effects of bLf in airway infections, here we evaluated the antibacterial and anti-inflammatory activities of aerosolized bLf in mice affected by acute and 
chronic $P$. aeruginosa lung infections. In both acute and chronic infections, aerosolized bLf determined not-significant reduction of bacterial load but significant decrease of the neutrophil recruitment and pro-inflammatory cytokine levels. Moreover, in chronic infection the bLf-treated mice recovered the body weight faster and at higher extent than the control mice. These findings add new data into the beneficial activity of bLf suggesting a putative therapeutic application in airway infections. 


\section{Materials and Methods}

\section{Bacterial strains, media, and culture conditions}

P. aeruginosa PAO1 (ATCC 15692) reference laboratory strain and MDR-RP73, a clinical strain isolated at late stage of chronic lung disease from CF patient (Jeukens et al. 2013) strains were checked for purity on Trypticase Soy Agar (TSA) plates (Becton Dickinson, Sparks, MD, USA). P. aeruginosa strains were grown in tryptic soy broth (TSB) (Becton Dickinson, Sparks, MD, USA) to reach the exponential phase. Next, the bacteria were pelleted by centrifugation $(2700 \mathrm{~g}, 15 \mathrm{~min}$, $4^{\circ} \mathrm{C}$ ) and washed twice with sterile PBS before the infection.

\section{Lactoferrin}

Highly purified bovine milk derivative Lf (bLf) was kindly provided by Morinaga Milk Industries Co., Ltd. (Tokyo, Japan). The purity and iron saturation of bLf were checked (Frioni et al. 2014). BLfiron saturation was of $15 \%$. LPS contamination of bLf was estimated by Limulus Amebocyte assay (LAL Pyrochrome kit, PBI International, Italy) and was equal to $0.5 \pm 0.04 \mathrm{ng} / \mathrm{mg}$ of bLf. Before use, bLf saline solutions were sterilized by $0.2 \mu \mathrm{m}$ filter (Millipore Corp., Bedford, Mass.).

\section{Ethic Statement}

Animal studies were conducted according to protocols approved by San Raffaele Scientific Institute (Milan, Italy) Institutional Animal Care and Use Committee (IACUC) and adhered strictly to the Italian Ministry of Health guidelines for the use and care of experimental animals.

\section{Animals, acute and chronic infection and treatments}

C57BL/6NCrl (8-10 weeks) male mice were purchased by Charles River (Italy). Mice were housed in filtered cages under specific-pathogen free conditions and permitted unlimited access to food and water. For lung infection, mice were anesthetized by intraperitoneal injection of 2.5 $\mathrm{mg}$ of 2,2,2-tribromethanol (Avertin, Sigma) in $0.9 \% \mathrm{NaCl}$ and administered in a volume of $15 \mu \mathrm{l} / \mathrm{g}$ of body weight. The trachea directly visualized by a ventral midline incision was exposed and 
intubated with a sterile, flexible 22-gauge catheter (Becton Dickinson, Madrid, Spain) attached to a $1 \mathrm{ml}$ syringe according to established procedures (Facchini et al. 2014). For acute lung infection, mice were infected with $50 \mu \mathrm{l}$ of $P$. aeruginosa PAO1 suspension containing $1.0 \pm 0.1 \times 10^{6}$ CFUs (Lore et al. 2012). For the chronic infection, mice were inoculated with $50 \mu$ of agar bead suspensions containing $1.0 \pm 0.1 \times 10^{6}$ CFUs of $P$. aeruginosa MDR-RP73 to mimic biofilm lifestyle (Facchini et al. 2014; Bianconi et al. 2015). P. aeruginosa strains were implanted via the cannula into the lung with both lobes inoculated.

For acute and chronic lung infection, a total of 19 and 33 mice, respectively, were randomly assigned to the different treatment groups. Treatments with aerosolized bLf or saline were started 5 min after infection. Mice were treated with $50 \mu$ l of freshly prepared solutions containing $100 \mu \mathrm{g}$ $(4,5 \mathrm{mg} / \mathrm{kg})$ or $200 \mu \mathrm{g}(9 \mathrm{mg} / \mathrm{kg})$ of bLf or sterile saline (control mice) by pulmonary administration with a micro-spray aerosol device (MicroSprayer aerosolizer model IA-C and FMJ-250 highpressure syringe; Penn-Century Inc. Windmoor, PA). For the model of acute infection, the mice received only one treatment with 100 or $200 \mu \mathrm{g}$ of aerosolized bLf and sacrificed after 6 hours with an overdose of carbon dioxide. For the model of chronic infection, the infected mice received one treatment each day with $200 \mu \mathrm{g}$ of freshly prepared bLf solutions or saline. The mice were treated from day 0 to day 6 and received a total of 7 treatments. After 6 hours from the last treatment, mice were killed with an overdose of carbon dioxide.

\section{Broncho-alveolar lavage (BAL) fluid collection and analysis}

The broncho-alveolar lavage (BAL) was performed three times with $1 \mathrm{ml}$ of RPMI 1640 with protease inhibitors (Complete tablets, Roche Diagnostic) with a 22-gauge venous catheter. Aliquot of BALs were both serially diluted 1:10 in PBS and plated for $P$. aeruginosa CFU counts, and used to perform the total cell counts. Thereafter BALs were centrifuged at $330 \mathrm{xg}$ for $8 \mathrm{~min}$ at $4{ }^{\circ} \mathrm{C}$ and supernatants were collected and stored at $-80^{\circ} \mathrm{C}$. Basing on the total cell counts, pellets were 
suspended in proper volume of RPMI plus $10 \%$ FBS to obtain about $1 \times 10^{6}$ cells $/ \mathrm{ml}$, and $150 \mu \mathrm{l}$ were used to perform differential cell count by cytospins stained with Diff Quick (Dade, Biomap, Italy).

\section{Lung homogenization and cytokine analysis}

Lungs were removed and homogenized in $2 \mathrm{ml}$ PBS containing protease inhibitors. Samples were serially diluted 1:10 in PBS and plated for CFU counts. Lung homogenates were then centrifuged at $16000 \mathrm{~g}$ for $30 \mathrm{~min}$ at $4^{\circ} \mathrm{C}$ and the supernatants were stored at $-80^{\circ} \mathrm{C}$ for cytokine and chemokine analysis. After quantification of total protein content with Bradford's assay (BioRAD, California 94547, USA), cytokine levels in supernatants were analyzed using the Bio-Plex Protein Array System (Bio-plex Pro Mouse Cytokine 23-Plex Immunoassay, Bio-Rad, California 94547, USA). The following inflammatory cytokines and chemokines were detected: IL-1 $\alpha$, IL-1 $\beta$, L2, IL-3, IL-4, IL-5, IL-6, IL-9, IL-10, IL-12(p40), IL-12(p70), IL-13, IL-17, Eotaxin, G-CSF, GM-CSF, IFN- $\gamma$, KC, MCP-1, MIP- $1 \alpha$, MIP-1 $\beta$, RANTES, and TNF- $\alpha$.

\section{Statistical analysis}

Results were derived from at least three independent experiments and reported as mean values \pm standard deviations. Two-way ANOVA with Bonferroni's multiple comparison test was used to compare change in body weight. For CFUs, cells and cytokines/chemokines levels analysis, One-way ANOVA followed by Bonferroni's analysis was used to compare three experimental groups and Mann-Whitney $U$ test to compare two experimental groups. The analyses were performed using Prism (GraphPad). Tests are considered statistically significant when the significance $P$ was $\leq 0.05$. 


\section{Results}

\section{Effect of aerosolized bLf on $P$. aeruginosa CFUs in lung homogenates and BALs}

To evaluate the antibacterial effect of aerosolized bLf, $P$. aeruginosa counts were performed in lung homogenates and BALs. A partial reduction of $P$. aeruginosa CFUs in bLf- respect to salinetreated mice was observed in both acute and chronic lung infections even if the differences did not reach statistical significance. Concerning acute infection, higher reduction of $P$. aeruginosa CFUs was observed in mice treated with 200 than $100 \mu \mathrm{g} / 50 \mu \mathrm{l} \mathrm{bLf}$ respect to control (Figure 1, panel A).

Similar results were yielded in chronic infections where $P$. aeruginosa CFUs were lower in bLfthan saline-treated mice even if at not significant values (Figure 1, panel B). However, the clearance of infection was observed in three out of $17(18 \%)$ bLf-treated mice while no bacterial clearance was observed in saline-treated mice.

\section{Effect of aerosolized bLf on inflammatory response}

To establish the activity of aerosolized bLf on inflammatory response, the total and differential counts of leukocytes in BALs as well as the cytokine/chemokine production in lung homogenates were examined. Concerning the counts of leukocytes, in acute infection a significant reduction of total cells in bLf-treated respect to control mice was showed (Figure 2, Panel A). The decrease of total BAL cells was observed in mice treated with both doses of aerosolized bLf. The reduction was bLf-dose dependent even if at not significant level and the highest reduction was observed in mice treated with the highest dose of bLf. When differential counts in BAL cells were performed, significant decreases were observed for neutrophils in bLf- in comparison with saline-treated mice, whereas macrophage counts did not differ in bLf- and saline-treated mice (Figure 2, Panel A). The highest reduction of neutrophils was observed in mice treated with highest dose of aerosolized bLf. 
Similar to acute infection, also in chronic infection a significant reduction of total BAL cells in bLf- respect to saline-treated mice was detected (Figure 2, Panel B). The significant decrease affected neutrophil population, whilst macrophage counts were similar in both bLf- and salinetreated mice (Figure 2, Panel B).

Cytokine/chemokine production on supernatants of lung homogenates of mice affected by acute and chronic infections was examined. Some cytokines were not expressed at all or expressed at very low levels and precisely: IL-2, IL-3, IL-5, IL-9, and GM-CSF. A total of 18 cytokines were expressed and as general rule, the levels of expressed cytokines were lower in chronic than in acute infection (Tables 1; Figure 3). The bLf treatments was ineffective on the levels of 10 cytokines (Table 1) and the decreased the expression of 8 cytokines (Figure 3).

In particular, in acute infection, the treatment with the $100 \mu \mathrm{g}$ of bLf was ineffective on cytokine levels, while the dose of $200 \mu \mathrm{g}$ bLf induced a significant decrease of 7 cytokines (IL-1 $\alpha$, KC, G-CSF, MIP-1 $\alpha$, IL-6, IL-12(p40), and IL-12(p70) ) (Figure 3).

In chronic infection, the treatment with $200 \mu \mathrm{g}$ of aerosolized bLf decreased the expression of several cytokines. In particular, IL-1 $\alpha, \mathrm{IL}-1 \beta$, and G-CSF levels were diminished at significant level, while those of KC, MIP-1 $\alpha$, IL-12(p40), and IL-12(p70) were reduced at not significant level (Figure 3). IL-6 was not detected in both bLf- and saline-treated mice (Figure 3).

Effect of aerosolized bLf on body weight of mice affected by $P$. aeruginosa chronic lung infection

Since the bacterial infection affect mouse health, body weight loss was checked twice a day as parameter of well-being (van Heeckeren 2006). The body weight of infected mice decreased rapidly after infection and then rose starting from at $3^{\text {rd }}$ (bLf-treated mice) and $4^{\text {th }}$ day (salinetreated mice). Significantly higher body weights were recorded in bLf- than saline treated-mice already at the $4^{\text {th }}$ day of treatment. At the end of experiment, bLf-treated mice regained the initial 
weight, while saline-treated mice did not recover completely (-15\% at day 6 compared to day 0$)$ (Figure 4). 


\section{Discussion}

In this paper, we evaluated the role of aerosolized bLf in mouse models of $P$. aeruginosa lung infections. This bacterium is a serious pathogen for CF patients (Lenney 2015) and causes infections difficult to eradicate (Gibson et al. 2003; Vidya et al. 2015). During the infection development in CF patients, $P$. aeruginosa switches from an acute virulent pathogen, characteristic of early infections, to a CF-adapted pathogen, typical of chronic infection stages (Gomez and Prince 2007; Bragonzi et al. 2009; Rau et al. 2010; Hogardt and Heesemann 2013). Here, we employed two $P$. aeruginosa strains to induce acute and chronic infections. PAO1 was used to induce acute infections as it shows the characteristics of a strain isolated in CF acute lung infection as high rate of virulence and mortality in infected mice (Bianconi et al. 2015); MDR-RP73 strain, isolated from chronic lung infection in a CF patient (Jeukens et al. 2013), was employed in chronic infection where this MDR-RP73 strain was embedded in agar beads to maintain the lung infection for several days thus avoiding spontaneous bacterial clearance (Facchini et al. 2014).

The infected mice were differently treated with aerosolized bLf according to the type of infection (i.e: acute or chronic). The use of bLf is justified by the fact that bLf is generally recognized as a safe substance by Food and Drug Administration (USA) and available in large quantities. Therefore, bLf is utilized in the majority of the in vitro studies as well as in clinical trials (see the ClinicalTrials.Gov site https://clinicaltrials.gov/ct2/home) to identify putative applications (Manzoni et al. 2014; Paesano et al. 2010, 2012, 2014).

In acute lung infection, the mice received only one treatment with aerosolized bLf to evaluate the early response to infection while in chronic infection the infected mice were treated for 6 days to evaluate the late response to chronic infection.

The treatment with aerosolized bLf decreased the bacterial load of about 0.5 logs of CFUs in both acute and chronic infections respect to control (Figure 1) even if did not reach statistical 
significance. This result is not surprising as in vitro experiments bLf did no exhibit a potent antibacterial activity against $P$. aeruginosa (Kamiya et al. 2012). Anyway, it is interesting to underline that in chronic infection $18 \%$ of the blf-treated mice cleared the infection as no $P$. aeruginosa was found in both BALs and lung homogenates.

The most relevant effect of aerosolized bLf was observed in inflammatory response. Firstly, the total and differential leukocyte counts were determined in BALs. The aerosol administration of bLf reduced significantly the leukocyte counts in both acute and chronic infection respect to controls. Interestingly, in acute infection the significant reduction of leukocytes was observed with both the doses of aerosolized bLf (100 and $200 \mu \mathrm{g}$ ) (Figure 2, Panel A). When the differential counts in both acute and chronic infections were evaluated, the decrease involved only the neutrophil populations, while the macrophages were not affected (Figure 2). Firstly, the mouse models used in this study were proven useful to test novel therapies targeted at reducing infection and/or inflammation (Bragonzi 2010; Cigana et al. 2016).

At the best of our knowledge, this is the first time that the influence of aerosolized bLf on neutrophil recruitments in lung infection is shown.

The cytokine/chemokine production was higher in acute than chronic infection (Figures 3; Tables 1). These results may be due to the different $P$. aeruginosa strains: PAO1 is able to induce a fast and high inflammatory responses (Tayabali et al. 2015) while the MDR-RP73 induces a low inflammatory response (Di Lorenzo et al. 2015).

The aerosolized bLf was ineffective in modulating some cytokines (Table 1 ) while others were reduced in both acute and chronic infection (Figure 3). In particular, the expression of IL-1 $\alpha$, IL-1 $\beta$, KC (analogous to human IL-8), G-CSF, IL-6, MIP-1 $\alpha$, IL-6, IL-12(p40), and IL-12(p70) was decreased even if at different extent (Figure 3). The decrease of IL-1 $\alpha$ and IL-1 $\beta$ could mitigate the harmful 
effects of $P$. aeruginosa infection as well as cell death, tissue destruction, and promotion of fever (Bergsbaken et al. 2009; Douglas et al. 2009; Palomo et al. 2014).

The reduced neutrophil recruitment mediated by bLf treatment is likely related to the decrease of KC as well as of G-CSF and MIP-1 $\alpha$, key molecules involved in neutrophil development and function (Lieschke et al. 1994; Natori et al. 2002; Frioni et al. 2014; Christensen et al. 2016). Interestingly, the bLf treatment did not annul the KC production as already shown in in vitro models for IL-8 (Berlutti et al. 2006; Valenti et al. 2011; Frioni et al. 2014). These data suggest a protective activity of bLf in reducing the neutrophil-mediated damage.

Concerning IL-6, its level was significantly lowered by bLf treatment in acute infection while it was not produced in chronic infection confirming its peculiar role in acute phase response (Figure 3) (Scheller et al. 2011). This interleukin together with IL-12(p40) and IL-12(p70) may play a relevant role in inflammatory response. As matter of the fact, both IL- 6 and IL-12 productions are markers of M1 inflammatory phenotype of macrophages whereas their decrease is consistent with the shift from M1 to M2 macrophage phenotype (Gordon 2003). Their decrease in bLf-treated mice together with the recent findings showing the bLf ability to up-regulate the down-expression of ferroportin (typical of M1 phenotype) in LPS-stimulated human macrophages (Cutone et al. 2014), let us to hypothesize that bLf may be a regulator of the shift of $M 1 / M 2$ macrophage phenotype thus reducing the inflammatory M1 damage.

Taken on the whole, the present data confirm the potent anti-inflammatory activity of bLf also in the context of respiratory infections. Even if the anti-inflammatory activity of aerosolized bLf has been described in the past (Elrod et al. 1997; Chen et al. 2014), this is the first time that the anti-inflammatory function of aerosolized bLf is shown in mice affected by acute and chronic $P$. aeruginosa lung infections. Significantly, the aerosolized bLf resulted in the improvement of well- 
being and health of infected mice since in chronic infection the bLf-treated mice recovered the body weight more rapidly and at higher extent than the control mice (Figure 4).

In conclusion, the aerosol administration of bLf had a multiple protective effect on infected mice: decreased $P$. aeruginosa load; decreased neutrophil recruitment as well as some proinflammatory cytokines/chemokines, and ameliorated the health of the infected mice. The exact mechanism of action of bLf is to be deepened and the reported data must be confirmed in CF mice.

These findings add new insights into the benefits of bLf as a mediator of general health and its potential therapeutic applications.

\section{Acknowledgements}

The research was granted by Cystic Fibrosis Foundation (Italy) (project FFC\#16/2014, sponsors Delegazione FFC di Torino, Gruppo di Sostegno FFC di Altamura Bari, and Trofeo di golf FFC 2015; project FFC\#12/2015, sponsor Delegazione FFC di Milano) to FB and by Sapienza University of Rome to PV and FB. 


\section{References}

Bergsbaken, T., Fink, S.L., and Cookson, B.T. 2009. Pyroptosis: host cell death and inflammation. Nat. Rev. Microbiol. 7(2): 99-109. doi:10.1038/nrmicro2070.

Berlutti, F., Schippa, S., Morea, C., Sarli, S., Perfetto, B., Donnarumma, G., and Valenti P. 2006. Lactoferrin downregulates pro-inflammatory cytokines upexpressed in intestinal epithelial cells infected with invasive or non invasive Escherichia coli strains. Biochem. Cell. Biol. 84(3): 351-357. doi:10.1139/o06-039.

Bianconi, I., Jeukens, J., Freschi, L., Alcalá-Franco, B., Facchini, M., Boyle, B., Molinaro, A., Kukavica-Ibrulj, I., Tümmler, B., Levesque, R.C., and Bragonzi, A. 2015. Comparative genomics and biological characterization of sequential Pseudomonas aeruginosa isolates from persistent airways infection. B.M.C. Genomics. 16(1): 1105. doi:10.1186/s12864.

Bragonzi, A. 2010. Murine models of acute and chronic lung infection with cystic fibrosis pathogens. Int. J. Med. Microbiol. 300(8): 584-593. doi:10.1016/j.ijmm.2010.08.012.

Bragonzi, A., Paroni, M., Nonis, A., Cramer, N., Montanari, S., Rejman, J., di Serio, C., Doring, G., and Tummler, B. 2009. Pseudomonas aeruginosa microevolution during cystic fibrosis lung infection establishes clones with adapted virulence. Am. J. Respir. Crit. Care Med. 180(2): 138-145. doi:10.1164/rccm.200812-19430C.

Chen, H.L., Yen, C.C., Wang, S.M., Tsai, T.C., Lai, Z.L., Sun, J.Y., Lin, W., Hsu, W.H., and Chen, C.M. 2014. Aerosolized bovine lactoferrin reduces lung injury and fibrosis in mice exposed to hyperoxia. Biometals. 27(5): 105710-105768. doi:10.1007/s10534-014-9750-7.

Christensen, A.D., Haase, C., Cook, A.D., and Hamilton, J.A. 2016. Granulocyte colonystimulating factor (G-CSF) plays an important role in immune complex-mediated arthritis. Eur. J. Immunol. 00:1-11. doi:10.1002/eji.201546185. 
Cigana, C., Lorè, N.I., Riva, C., De Fino, I., Spagnuolo, L., Sipione, B., Rossi, G., Nonis, A., Cabrini, G., and Bragonzi, A. 2016. Tracking the immunopathological response to Pseudomonas aeruginosa during respiratory infections. Sci. Rep. 6: 21465. doi:10.1038/srep21465.

Cohen, T.S., and Prince, A. 2012. Cystic fibrosis: a mucosal immunodeficiency syndrome. Nat. Med. 18(4): 509-519. doi:10.1038/nm.2715.

Cutone, A., Frioni, A., Berlutti, F., Valenti, P., Musci, G., and Bonaccorsi di Patti, MC. 2014. Lactoferrin prevents LPS-induced decrease of the iron exporter ferroportin in human monocytes/macrophages. Biometals 27(5):807-13. doi: 10.1007/s10534-014-9742-7.

Dakin, C.J., Numa, A.H., Wang, H., Morton, J.R., Vertzyas, C.C., and Henry, R.L. 2002. Inflammation, infection and pulmonary function in infants and young children with cystic fibrosis. Am. J. Respir. Crit. Care Med. 165(7): 904-910. doi:10.1164/ajrccm.165.7.2010139.

Di Lorenzo, F., Silipo, A., Bianconi, I., Lore', N.I., Scamporrino, A., Sturiale, L., Garozzo, D., Lanzetta, R., Parrilli, M., Bragonzi, A., and Molinaro, A. 2015. Persistent cystic fibrosis isolate Pseudomonas aeruginosa strain RP73 exhibits an under-acylated LPS structure responsible of its low inflammatory activity.Mol Immunol. 63(2): 166-175. doi:10.1016/j.

Douglas, T.A., Brennan, S., Gard, S., Berry, L., Gangell, C., Stick, S.M., Clements, B.S., and Sly P.D. 2009. Acquisition and eradication of $P$. aeruginosa in young children with cystic fibrosis. Eur. Respir. J. 33(2): 305-311. doi:10.1183/09031936.00043108.

Elrod, K.C., Moore, W.R., Abraham, W.M., and Tanaka, R.D. 1997. Lactoferrin, a potent tryptase inhibitor, abolishes late-phase airway responses in allergic sheep. Am. J. Respir. Crit. Care Med. 156(2 Pt 1): 375-381. doi:10.1164/ajrccm.156.2.9607012.

Facchini, M., De Fino, I., Riva, C., and Bragonzi, A. 2014. Long term chronic Pseudomonas aeruginosa airway infection in mice. J. Vis. Exp. (85):51019. doi:10.3791/51019. 
Frioni, A., Conte, M.P., Cutone, A., Longhi, C., Musci, G., di Patti, M.C., Natalizi, T., Marazzato, M., Lepanto, M.S., Puddu, P., Paesano, R., Valenti, P., and Berlutti, F. 2014. Lactoferrin differently modulates the inflammatory response in epithelial models mimicking human inflammatory and infectious diseases. Biometals. 27(5): 843-856. doi:10.1007/s10534014-9740-9.

Gibson, R.L., Burns, J.L., and Ramsey, B.W. 2003. Pathophysiology and management of pulmonary infections in cystic fibrosis. Am. J. respire. Crit. care med. 168(8): 918-951. doi:10.1164/rccm.200304-505SO.

Gomez, M.I., and Prince, A. 2007. Opportunistic infections in lung disease: Pseudomonas infections in cystic fibrosis. Curr. Opin. Pharmacol. 7(3): 244-251. doi:10.1016/j.coph.2006.12.005.

Gordon, S. 2003. Alternative activation of macrophages. Nat. rev. Immunol. 3(1): 23-35. doi:10.1038/nri978.

Hogardt, M., and Heesemann, J. 2013. Microevolution of Pseudomonas aeruginosa to a chronic pathogen of the cystic fibrosis lung. Curr. Top. Microbiol. Immunol. 358: 91-118. doi:10.1007/82_2011_199.

Jeukens, J., Boyle, B., Bianconi, I., Kukavica-Ibrulj, I., Tümmler, B., Bragonzi, A., and Levesque, R.C. 2013. Complete genome sequence of persistent Cystic Fibrosis isolate Pseudomonas aeruginosa strain RP73. Genome Announc. 1(4): e00568-13. doi:10.1128/genomeA.00568-13.

Kamiya, H., Ehara, T., and Matsumoto, T. 2012. Inhibitory effects of lactoferrin on biofilm formation in clinical isolates of Pseudomonas aeruginosa. J. Infect. Chemother. 18(1): 47-52. doi:10.1007/s10156-011-0287-1.

Latorre, D., Berlutti, F., Valenti, P., Gessani, S., and Puddu, P. 2012. LF immunomodulatory strategies: mastering bacterial endotoxin. Biochem. Cell Biol. 90(3): 269-278. doi:10.1139/o11059. 
Legrand, D. 2012. Lactoferrin, a key molecule in immune and inflammatory processes. Biochem. Cell Biol. 90(3): 252-268. doi:10.1139/o11-056.

Lenney, W. 2015. Pseudomonas aeruginosa in cystic fibrosis is potentially serious, and more than merely a marker for disease severity. Paediatr. Respir. Rev. 16 Suppl 1: 35-36. doi:10.1016/j.prrv.2015.07.016.

Lieschke, G.J., Grail, D., Hodgson, G., Metcalf, D., Stanley, E., Cheers, C., Fowler, K.J., Basu, S., Zhan, Y.F., and Dunn, A.R. 1994. Mice lacking granulocyte colony-stimulating factor have chronic neutropenia, granulocyte and macrophage progenitor cell deficiency, and impaired neutrophil mobilization. Blood. 84(6): 1737-1746.

Lore, N.I., Cigana, C., De Fino, I., Riva, C., Juhas, M., Schwager, S., Eberl, L., and Bragonzi, A. 2012. Cystic fibrosis-niche adaptation of Pseudomonas aeruginosa reduces virulence in multiple infection hosts. PLoS One 7(4): e35648. doi:10.1371/journal.pone.0035648.

Manzoni, P., Meyer, M., Stolfi, I., Rinaldi, M., Cattani, S., Pugni, L., Romeo, M.G., Messner, H., Decembrino, L., Laforgia, N., Vagnarelli, F., Memo, L., Bordignon, L., Maule, M., Gallo, E., Mostert, M., Quercia, M., Bollani, L., Pedicino, R., Renzullo, L., Betta, P., Ferrari, F., Alexander, T., Magaldi, R., Farina, D., Mosca, F., and Stronati, M. 2014. Bovine lactoferrin supplementation for prevention of necrotizing enterocolitis in very-low-birth-weight neonates: a randomized clinical trial. Early Hum. Dev. 90 Suppl 1: S60-65. doi:10.1016/S0378-3782(14)70020-9.

Natori, T., Sata, M., Washida, M., Hirata, Y., Nagai, R., and Makuuchi, M. 2002. G-CSF stimulates angiogenesis and promotes tumor growth: potential contribution of bone marrow-derived endothelial progenitor cells. Biochem. Biophys. Res. Commun. 297(4): 1058-1061. doi:10.1016/S0006-291X(02)02335-5.

O'Sullivan, B.P., and Flume, P. 2009. The clinical approach to lung disease in patients with cystic fibrosis. Semin. Respir. Crit. Care Med. 30(5): 505-513. doi:10.1055/s-0029-1238909. 
Paesano, R., Berlutti, F., Pietropaoli, M., Goolsbee, W., Pacifici, E., and Valenti, P. 2010. Lactoferrin efficacy versus ferrous sulfate in curing iron disorders in pregnant and non-pregnant women. Int. J. Immunopathol. Pharmacol. 23(2): 577-587.

Paesano, R., Pacifici, E., Benedetti, S., Berlutti, F., Frioni, A., Polimeni, A., and Valenti, P. 2014. Safety and efficacy of lactoferrin versus ferrous sulphate in curing iron deficiency and iron deficiency anaemia in hereditary thrombophilia pregnant women: an interventional study. Biometals. 27(5): 999-1006. doi:10.1007/s10534-014-9723-x.

Paesano, R., Pietropaoli, M., Berlutti, F., and Valenti, P. 2012. Bovine lactoferrin in preventing preterm delivery associated with sterile inflammation. Biochem. Cell Biol. 90(3): 468-475. doi:10.1139/o11-060.

Palomo, J., Marchiol, T., Piotet, J., Fauconnier, L., Robinet, M., Reverchon, F., Le Bert, M., Togbe, D., Buijs-Offerman, R., Stolarczyk, M., Quesniaux, V.F., Scholte, B.J., and Ryffel, B. 2014. Role of IL$1 \beta$ in experimental cystic fibrosis upon $P$. aeruginosa infection. PLoS One. 9(12):e114884. doi:10.1371/journal.pone.0114884.

Rau, M.H., Hansen, S.K., Johansen, H.K., Thomsen, L.E., Workman, C.T., Nielsen, K.F., Jelsbak, L., Hoiby, N., Yang, L., and Molin, S. 2010. Early adaptive developments of Pseudomonas aeruginosa after the transition from life in the environment to persistent colonization in the airways of human cystic fibrosis hosts. Environ. Microbiol. 12(6): 1643-1658. doi:10.1111/j.1462-2920.2010.02211.x.

Reid, D.W., Carroll, V., O’May, C., Champion, A., and Kirov, S.M. 2007. Increased airway iron as a potential factor in the persistence of Pseudomonas aeruginosa infection in cystic fibrosis. Eur. Respir. J. 30(2):286-292. doi:10.1183/09031936.00154006.

Scheller, J., Chalaris, A., Schmidt-Arras, D., and Rose-John, S. 2011. The pro- and antiinflammatory properties of the cytokine interleukin-6. Biochim. Biophys. Acta. 1813(5): 878-888. doi:10.1016/j.bbamcr.2011.01.034. 
Smith, D.J., Anderson, G.J., Bell, S.C., and Reid, D.W. 2014. Elevated metal concentrations in the CF airway correlate with cellular injury and disease severity. J. Cyst. Fibros. 13(3): 289-295. doi:10.1016/j.jcf.2013.12.001.

Tayabali, A.F., Coleman, G., Nguyen, K.C. 2015. Virulence attributes and host response assays for determining pathogenic potential of pseudomonas strains used in biotechnology. PLoS One. 10(11): e0143604. doi:10.1371/journal.pone.0143604.

Travis, S.M., Conway, B.A.D., Zabner, J., Smith, J.J., Anderson, N.N., Singh, P.K., Greenberg, E.P., Welsh, M.J. 1999. Activity of abundant antimicrobials of the human airway. Am. J. Cell Mol. Biol. 20(5): 872-879. doi:10.1165/ajrcmb.20.5.3572.

Valenti, P., and Antonini, G. 2005. Lactoferrin: an important host defence against microbial and viral attack. Cell. Mol. Life Sci. 62(22): 2576-2587. doi:10.1007/s00018-005-5372-0.

Valenti, P., Berlutti, F., Conte, M.P., Longhi, C., and Seganti, L. 2004. Lactoferrin functions: current status and perspectives. J. Clin. Gastroenterol. 38(6 Suppl): S127-129.

Valenti, P., Catizone, A., Pantanella, F., Frioni, A., Natalizi, T., Tendini, M., and Berlutti, F. 2011. Lactoferrin decreases inflammatory response by cystic fibrosis bronchial cells invaded with Burkholderia cenocepacia iron-modulated biofilm. Int. J. Immunopathol. Pharmacol. 24(4): 10571068.

Verhaeghe, C., Delbecque, K., de Leval, L., Oury, C., and Bours, V. 2007. Early inflammation in the airways of a cystic fibrosis foetus. J. Cyst. Fibros. 6(4): 304-308. doi:10.1016/j.jcf.2006.12.001.

Vidya, P., Smith, L., Beaudoin, T., Yau, Y.C., Clark, S., Coburn, B., Guttman, D.S., Hwang, D.M., and Waters, V. 2015. Chronic infection phenotypes of Pseudomonas aeruginosa are associated with failure of eradication in children with cystic fibrosis. Eur. J. Clin. Microbiol. Infect. Dis. doi:10.1007/s10096-015-2509-4. 
Waters, V., and Smyth, A. 2015. Cystic fibrosis microbiology: advances in antimicrobial therapy. J. Cyst. Fibros. 14(5): 551-560. doi:10.1016/j.jcf.2015.02.005. 


\begin{tabular}{|c|c|c|c|c|c|}
\hline & \multicolumn{3}{|c|}{ P. aeruginosa acute infection } & \multicolumn{2}{|c|}{$\begin{array}{l}\text { P. aeruginosa chronic } \\
\text { infection }\end{array}$} \\
\hline & Saline & $\begin{array}{c}\text { bLf } \\
(100 \mu \mathrm{g} / 50 \mu \mathrm{l})\end{array}$ & $\begin{array}{c}\text { bLf } \\
(200 \mu \mathrm{g} / 50 \mu \mathrm{l})\end{array}$ & Saline & $\begin{array}{c}\text { bLf } \\
(200 \mu \mathrm{g} / 50 \mu \mathrm{l})\end{array}$ \\
\hline IL-4 (pg/ml) & $11.0 \pm 2.8$ & $11.4 \pm 2.8$ & $7.7 \pm 2.6$ & $8 \pm 3.4$ & $7.5 \pm 2.9$ \\
\hline IL-10 (pg/ml) & $10.3 \pm 3.5$ & $12.0 \pm 2.7$ & $9.9 \pm 2.4$ & $9.8 \pm 5.8$ & $7.5 \pm 4.4$ \\
\hline IL-13 (pg/ml) & $156.3 \pm 41.0$ & $135.9 \pm 10.1$ & $155.5 \pm 16.4$ & $136.1 \pm 40.1$ & $139.0 \pm 48.0$ \\
\hline IL-17 (pg/ml) & $12.5 \pm 1.5$ & $11.7 \pm 1.3$ & $12.5 \pm 0.7$ & $46.4 \pm 17.7$ & $29.6 \pm 24.8$ \\
\hline Eotaxin $(\mathrm{pg} / \mathrm{ml})$ & $240.4 \pm 187.5$ & $413.2 \pm 227.0$ & $413.2 \pm 251.2$ & $295.9 \pm 402.5$ & $321.6 \pm 343.8$ \\
\hline IFN- $\gamma(\mathrm{pg} / \mathrm{ml})$ & $10.8 \pm 6.0$ & $9.4 \pm 6.7$ & $7.7 \pm 1.7$ & $3.7 \pm 3.2$ & $3.4 \pm 2.3$ \\
\hline MCP-1 (pg/ml) & $1396.9 \pm 296.4$ & $954.9 \pm 256.9$ & $1018.6 \pm 350.6$ & $266.5 \pm 88.1$ & $207.7 \pm 125.9$ \\
\hline MIP-1 $(\mathrm{pg} / \mathrm{ml})$ & $57.3 \pm 13.1$ & $62.2 \pm 10.6$ & $41.9 \pm 4.6$ & $43.6 \pm 19.9$ & $32.8 \pm 12.5$ \\
\hline RANTES (pg/ml) & $27.6 \pm 1.9$ & $37.0 \pm 7.6$ & $27.1 \pm 4.5$ & $81.5 \pm 34.3$ & $76.3 \pm 47.3$ \\
\hline TNF- $\alpha(\mathrm{pg} / \mathrm{ml})$ & $13.9 \pm 5.7$ & $9.2 \pm 2.1$ & $14.9 \pm 1.7$ & $9.5 \pm 4.0$ & $10.7 \pm 3.7$ \\
\hline
\end{tabular}

TABLE 1. Cytokine production in lung homogenates

Cytokine concentrations are expressed as mean values \pm standard deviations; mice were treated with aerosolized saline or bovine lactoferrin (bLf). 


\section{Figure captions}

Figure 1. Pseudomonas aeruginosa counts in lung homogenates and BALs

Legend: Panel A: CFUs of $P$. aeruginosa PAO1 in the acute model were evaluated 6 hours after challenge; Panel B: CFUs of P. aeruginosa MDR-RP73 in the chronic model were evaluated 6 days after challenge (for details see M\&M Section); mice were treated with aerosol administration of 50 $\mu \mathrm{l}$ saline (black dots), $100 \mu \mathrm{g} / 50 \mu \mathrm{l}$ bovine lactoferrin (bLf) (light grey dots), or $200 \mu \mathrm{g} / 50 \mu \mathrm{l}$ bLf (dark grey dots).

Figure 2. Total and differential leukocyte counts in BALs

Legend: Panel A: P. aeruginosa PAO1 acute lung infection; Panel B: P. aeruginosa MDR-RP73 chronic lung infection; left Panels: total leukocyte counts; right panels; neutrophil and macrophage counts; mice were treated with aerosol administration of $50 \mu \mathrm{l}$ saline (black dots), $100 \mu \mathrm{g} / 50 \mu \mathrm{l}$ bovine lactoferrin (bLf) (light grey dots), or $200 \mu \mathrm{g} / 50 \mu \mathrm{l} \mathrm{bLf}$ (dark grey dots); ${ }^{*} P<0.05$; ${ }^{* *} P<0.01$; $* * * P<0.005$.

Figure 3. Effect of aerosolized bovine lactoferrin on cytokine expression in acute and chronic

\section{$P$. aeruginosa lung infection}

Legend: mice treated with aerosol administration of $50 \mu \mathrm{l}$ saline (black bars), $100 \mu \mathrm{g} / 50 \mu \mathrm{l}$ bovine lactoferrin (bLf) (light grey bars), or $200 \mu \mathrm{g} / 50 \mu \mathrm{l}$ bLf (dark grey bars); ${ }^{*} P<0.05 ;{ }^{* *} P<0.01$; ND: not detected.

\section{Figure 4. Body weight of mice suffering from $P$. aeruginosa MDR-RP73 chronic lung infection}

Legend: mice were challenged with $P$. aeruginosa MDR-RP73 at day 0 and treated seven times (I-VII treatments, days 0-6) with aerosol administration of $50 \mu \mathrm{l}$ saline (black line) or $200 \mu \mathrm{g} / 50 \mu \mathrm{l}$ bovine lactoferrin (bLf) (grey line) for six days (1-6 days); ${ }^{*} P<0.05$. 

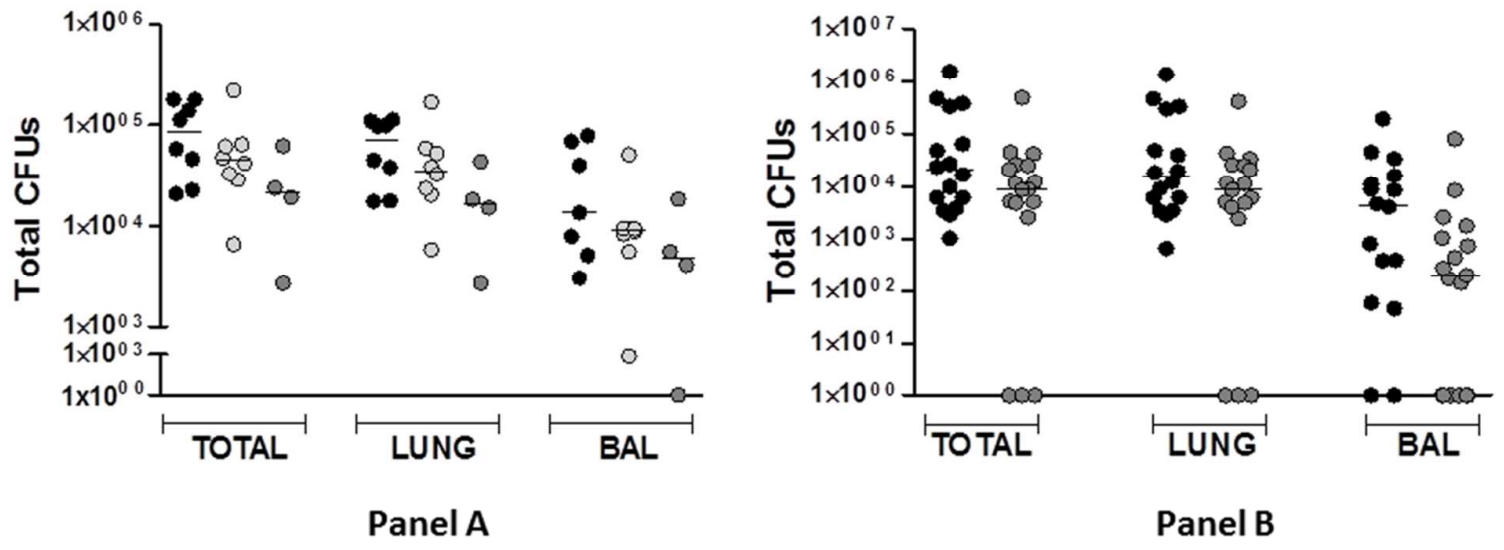

Figure 1 

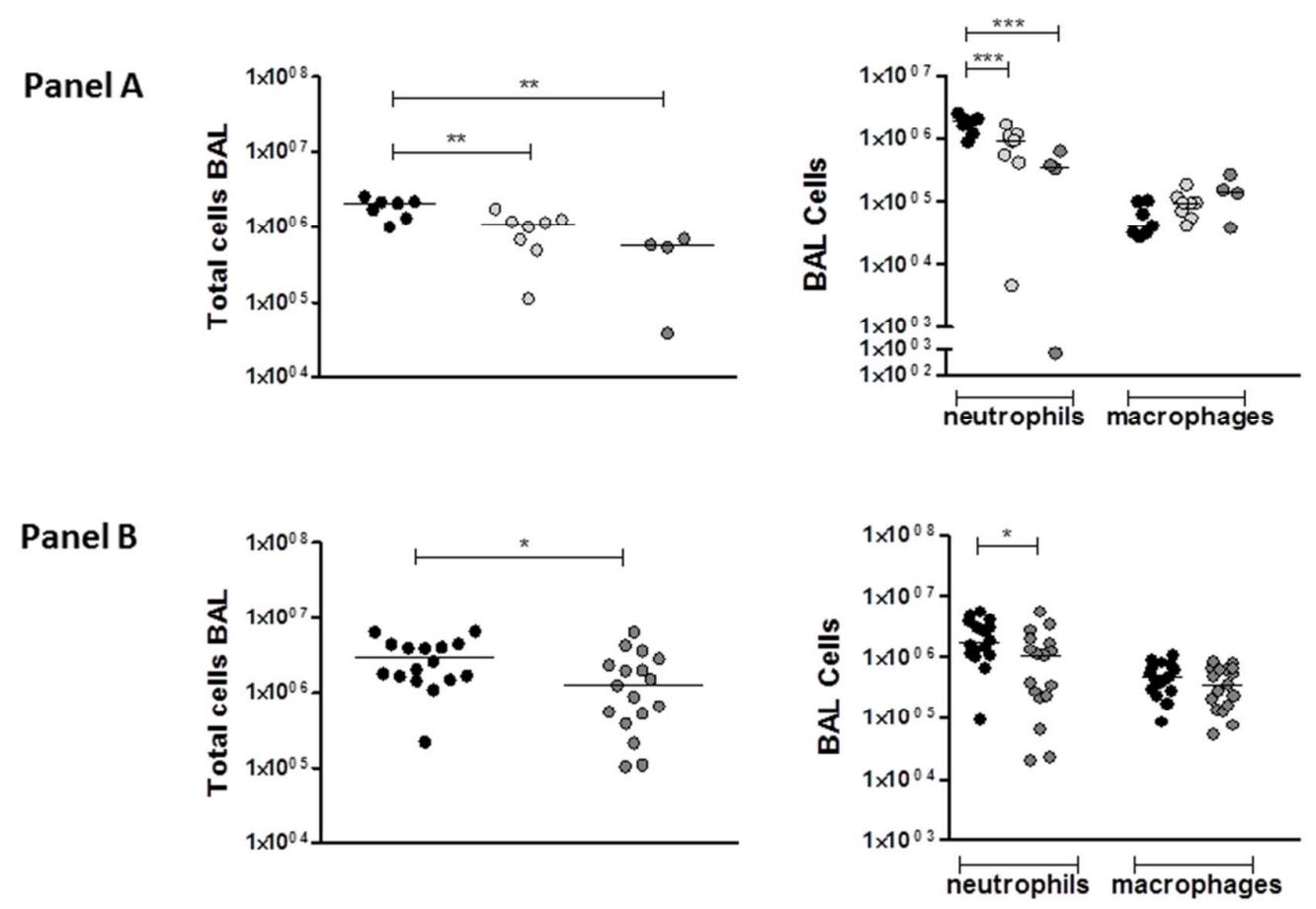

Figure 2 
$\mathrm{IL}-1 \alpha$

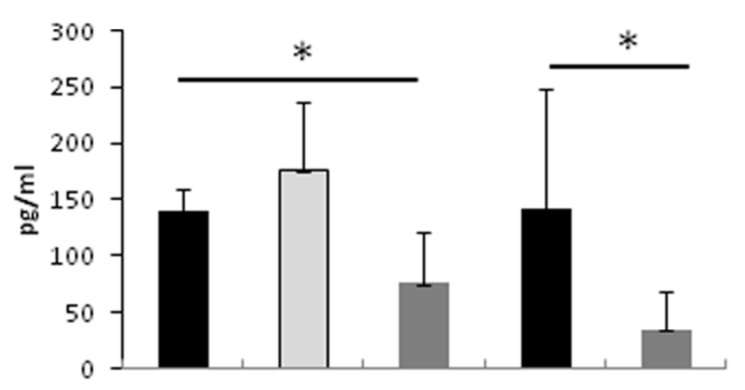

KC

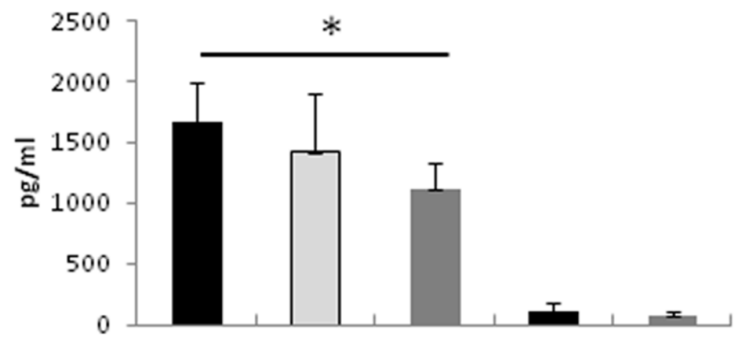

MIP-1 $\alpha$

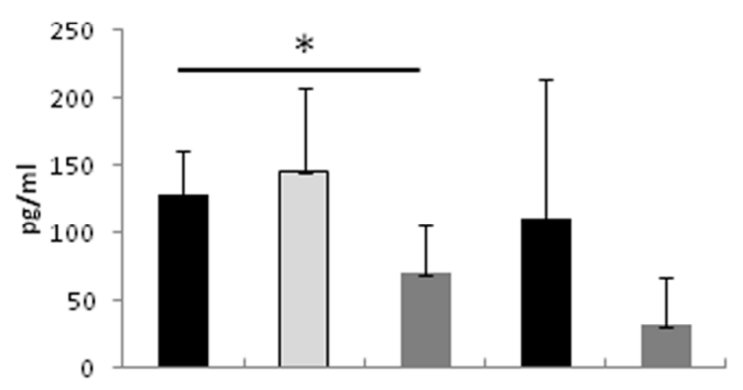

IL-12(p40)

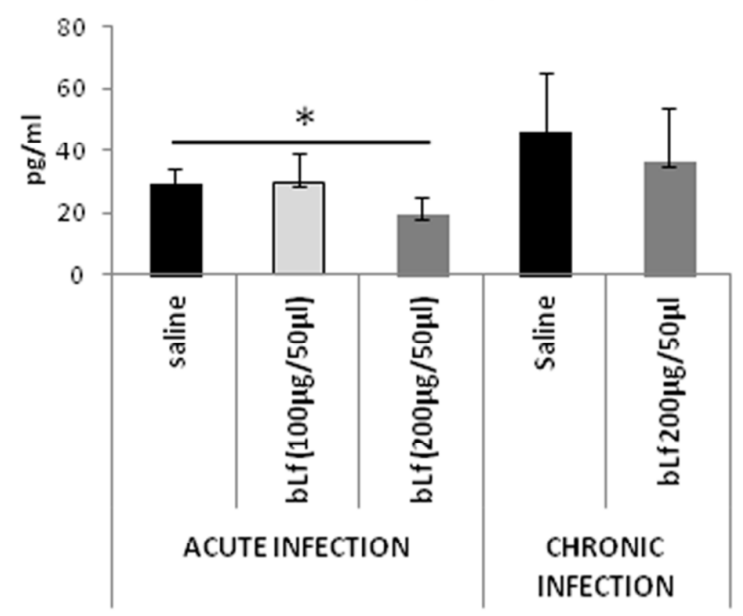

IL-1 $\beta$
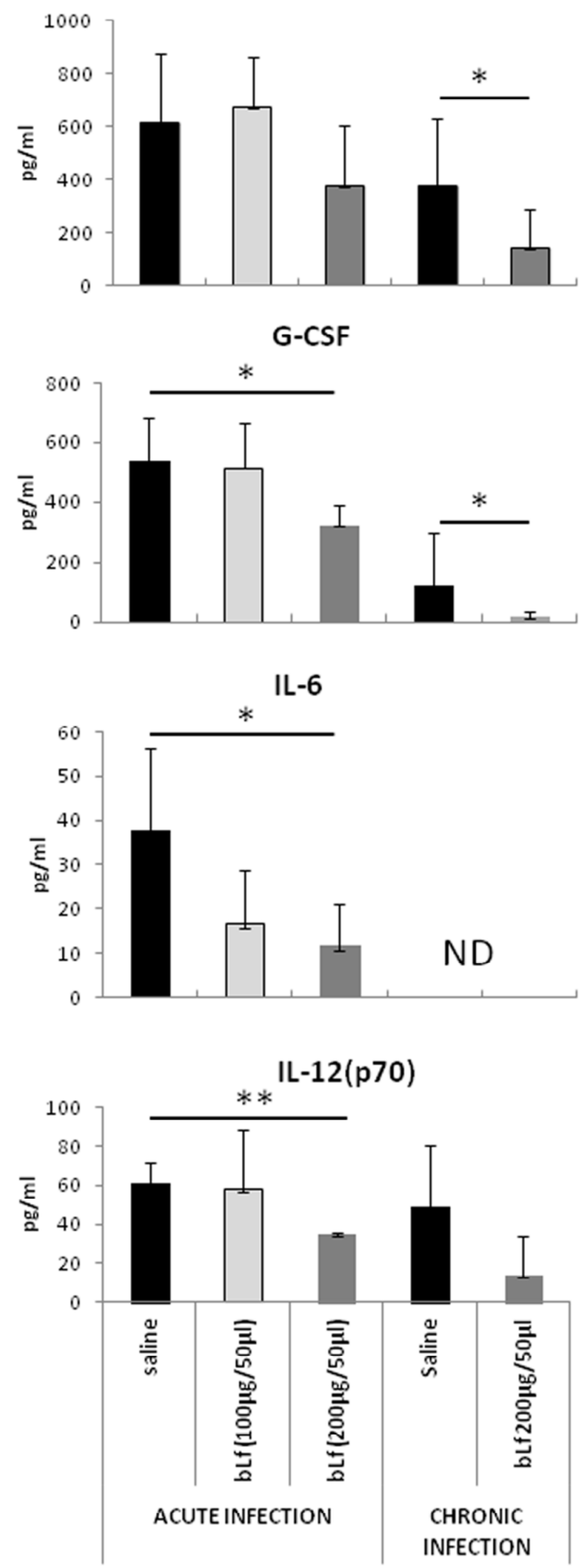

Figure 3 


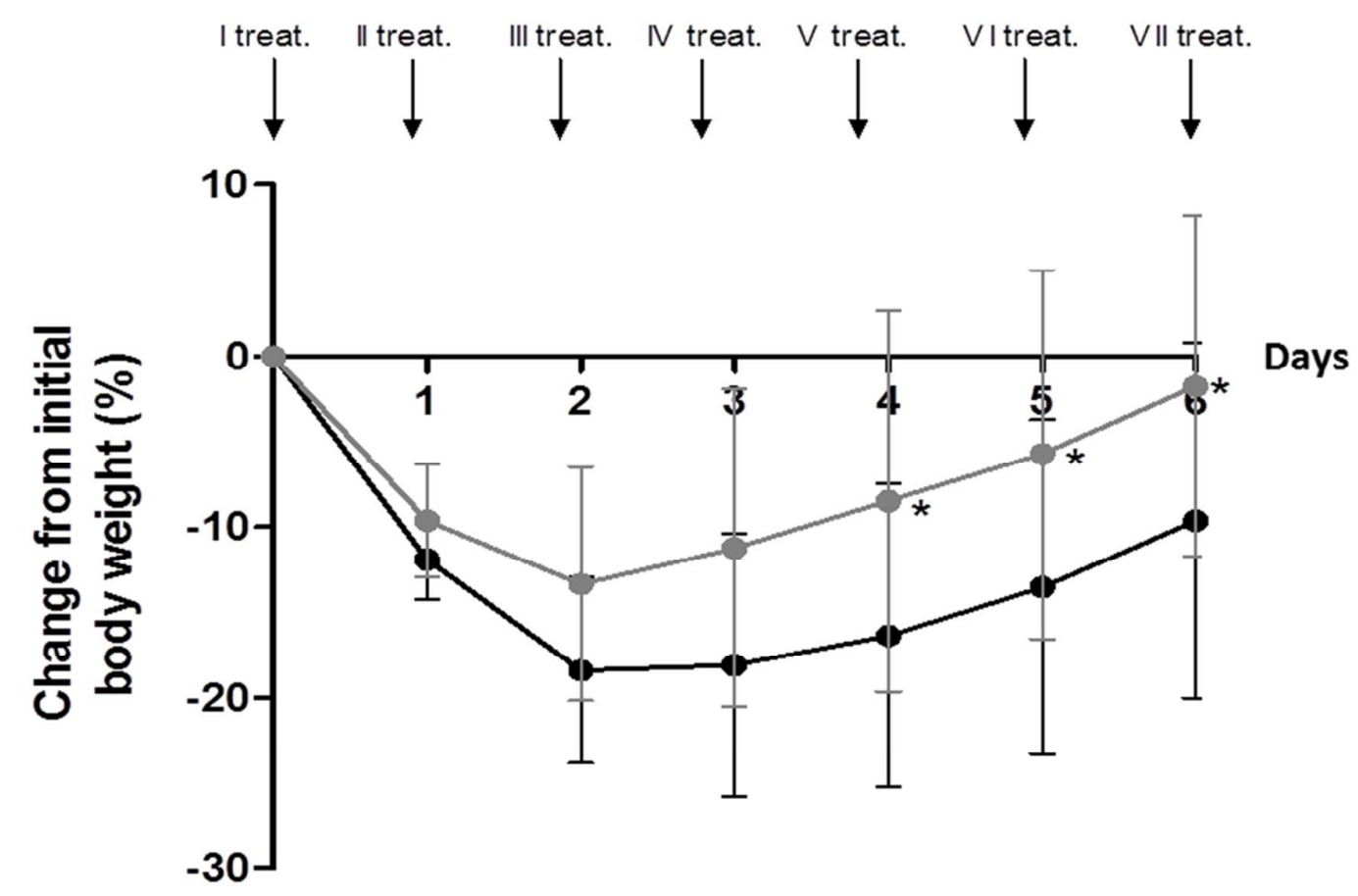

Figure 4 